\title{
The Intersection of Biblical Lament and Psychotherapy in the Healing of Trauma Memories
}

\author{
JUNE F DiCKIE (UNIVERSITY OF KWAZULU-NATAL)
}

\begin{abstract}
A study of biblical lament psalms can help present-day sufferers express their own pain to God, and this can result in personal, social, and biological healing. In this empirical study, Zulu "pain-bearers" first studied Psalms 3 and 13 and then wrote and performed their own laments, using the biblical laments as a model. The use of poetic form is shown to have advantages over narrative therapy approaches.

The empirical compositions and performances fit with the insights gained from cognitive psychotherapy approaches as well as the therapeutic steps proposed by Judith Herman. Moreover, apart from facilitating healing of the soul and interpersonal relations, the research insights of Cozolino and others suggest that lament can stimulate the biological healing of the brain, allowing for the healthy processing of the trauma memories.
\end{abstract}

KEYWORDS: Psalms of Lament, Psychotherapy, Trauma memories, Community participation, Poetic form.

\section{A THIS STUDY WITHIN THE FIELD OF PSYCHOLOGICAL HERMENEUTICS APPLIED TO BIBLICAL STUDIES}

Since the 1960s, biblical scholars have given increasing attention to the psychological, sociological, political and economic aspects of human suffering. ${ }^{1}$ In particular, there has been a growing interest in examining biblical texts "through the lens of trauma". 2 Such a hermeneutic provides "a framework"3 which sensitizes the exegete to connections between traumatic historical events and literary texts, both their production and appropriation. It allows us to see that

* Submitted: 27/11/2018; peer-reviewed: 10/10/2019; accepted: 21/10/2019. June F. Dickie, "The Intersection of Biblical Lament and Psychotherapy in the Healing of Trauma Memories," Old Testament Essays 32 no. 3 (2019): 885 - 907. DOI: https://doi. org/10.17159/2312-3621/2019/v32n3a7.

See Judith L. Herman, Trauma and Recovery: The Aftermath of Violence - From Domestic Abuse to Political Terror (New York: Basic Books, 1992), 7-9 for a comprehensive account of the historical development of trauma studies.

2 Christopher G. Frechette and Elizabeth Boase, "Defining 'Trauma' as a Useful Lens for Biblical Interpretation" in Bible through the lens of trauma (eds. Elizabeth Boase and Christopher G. Frechette; Atlanta: SBL Press, 2016).

3 David G. Garber Jr., "Trauma Theory and Biblical Studies", Currents in Biblical Research, (2015): 24-25. 
language relates to traumatic experiences in two ways: first, language reveals the effects of the trauma, and second, language creates mechanisms of survival, recovery and resilience. ${ }^{4}$

Most work by biblical scholars has been done in the former domain, looking at texts of violence or pain and seeking to identify the trauma underlying the accounts. For example, many focus on the message of biblical prophets, such as Jeremiah, ${ }^{5}$ Isaiah, ${ }^{6}$ Ezekiel, ${ }^{7}$ Nahum, ${ }^{8}$ Micah, ${ }^{9}$ and Joel. ${ }^{10}$ Such scholars explain how written prophecy helped people cope in the aftermath of trauma, giving meaning to "shocking occurrences". ${ }^{11}$ Following war and community dislocation, the prophetic writings assisted in the re-ordering of values and the creating of new symbolic and social worlds. ${ }^{12}$

More recently, trauma studies has moved beyond a focus on the prophetic writings to include other biblical texts, ${ }^{13}$ such as Genesis ${ }^{14}$ and Exodus. ${ }^{15}$ In these studies, the focus is still on how ancient victims testified to their traumatic experiences. However, some scholars are recognizing the need to mine ancient

4 Frechette and Boase, "Defining 'Trauma' as a Useful Lens", 12-13.

5 E.g., L. Juliana Claassens, "Preaching the Pentateuch: reading Jeremiah's sermons through the lens of cultural trauma", Scriptura, 116/2 (2017). Also,_Louis Stulman, "Reflections on the Prose Sermons in the Book of Jeremiah: Duhm's and Mowinckel's Contributions to Contemporary Trauma Readings" in Bible through the lens of Trauma (eds. Christopher Frechette and Elizabeth Boase; Atlanta: SBL, 2016).

6 Elizabeth Esterhuizen, "A Study of the Tension between Despair and Hope in Isaiah 7 and 8 from a Perspective of Trauma and Posttraumatic Growth" (D.Th thesis, UNISA, 2017).

7 Ruth Poser, "No Words: The Book of Ezekiel as Trauma Literature and a Response to Exile" in Bible through the lens of Trauma (eds. Christopher Frechette and Elizabeth Boase; Atlanta: SBL, 2016).

8 Klaas Spronk, "The avenging God of Nahum as comforter of the traumatized", Acta Theologica, 38, suppl.26 (2018).

9 Alphonso Groenewald, "Micah 4: 1-5 and a Judean experience of trauma", Scriptura, 116/2 (2017).

10 Micah L. Haney, "Reading Joel as a Rhetorical-Therapeutic Response to Trauma" (Ph.D thesis, Fuller Theological Seminary), 2019.

11 Ron Eyerman, "Social Theory and Trauma," Acta Sociologica 56/1 (2013):41.

12 Louis Stulman, "Reading the Bible through the Lens of Trauma and Art" in Trauma and Traumatization in Individual and Collective Dimensions: Insights from Biblical Studies and Beyond, (eds. Eve-Marie Becker, Jan Dochhorn, and Else Holt; Göttingen: Vandenhoeck \& Ruprecht, 2014), 189.

13 Garber, "Trauma Theory and Biblical Studies", 25.

14 Eleanor C. Craig, “'Un Imaginable Boundaries': Performativity, Theology, and the Study of Trauma" (D.Th thesis, Harvard Divinity School), 2017.

15 Kathleen Rochester, "Reading the Exodus Story Alongside Case Studies of Abuse and Betrayal in Family Relationships", The Expository Times (2018). Online: https://journals.sagepub.com/doi/abs/10.1177/0014524617731664. 
biblical texts to serve people today, as they process their own traumatic experiences. This study fits into the latter domain, applying biblical text to help contemporary sufferers. In this area of work, Janzen's comment is particularly apt: "The use of trauma theory in the field of biblical studies is still in its infancy." 16

Wayne Rollins, who in 1991 inaugurated the "Psychology and Biblical Studies Group" of the Society of Biblical Literature, suggests several areas for research, among which are "recognizing the biblical text and biblical interpretation as part of a psychic process in which conscious as well as unconscious factors are at work" and studying the "psycho-dynamic factors in biblical texts". ${ }^{17}$ As noted, this is where most prior research has concentrated. However, Rollins also includes the need to study "levels of meaning a text can evoke in readers" and "different modes of 'actualizing' the text". These latter goals are the concern of this empirical work.

\section{B INTRODUCTION TO THIS ARTICLE}

Psychological theories, especially those relating to the effects of trauma and criteria for healing, intersect with an understanding of biblical lament and the advantages it offers for trauma sufferers. The major problematic effects of trauma are damage to the soul (a loss of confidence in "who one is") and the intrusive nature of frightening memories. Biblical lament can contribute to the restoration of the soul, the replacement of negative memories with positive ones, and also facilitate the biological healing of the brain, allowing the raw memories to be properly processed so that they no longer intrude as unwanted flashbacks.

In this paper attention is first given to the impact of trauma on the brain, and in particular to the disruption in the processing of memories. This requires an understanding of the way the limbic system operates, to transform raw sensory data into long-term memories. There are two main views as to how trauma impacts this process, but both agree that the intrusive, negative memories need to be transformed. The approach of cognitive psychotherapy is then considered, with two theories being briefly mentioned. Principles which emerge from these theories will be used as a way of evaluating the method proposed in this article.

Several approaches to the healing of trauma utilize verbal means, often encouraging the sufferer to compose a trauma narrative. In this study, the advantages of poetry are suggested, particularly the use of memorable metaphors

16 David Janzen, The Violent Gift. Trauma's Subversion of the Deuteronomistic History's Narrative. LHB/OTS 561 (New York/London: Bloomsbury, 2012), 238.

17 Wayne G. Rollins, "The Bible and Psychology: New Directions in Biblical Scholarship," Pastoral Psychology, 45 (1997). Online: https://doi.org/10.1007/ $\underline{\mathrm{BF} 02251483}$. 
to replace the troublesome images. The characteristics of biblical poems which complain about difficult circumstances are then studied to explore features that could be incorporated into contemporary laments. For this study, Psalms 3 and 13 are used as examples of individual laments. In the empirical work, participants (Zulu youth who are "pain-bearers") write and perform their own poems, incorporating some of the features of biblical lament. The characteristics of this process are compared with those suggested by trauma therapists as being essential for healing, and conclusions are made as to how lament could assist within the therapeutic program.

\section{THE IMPACT OF TRAUMA ON THE BRAIN}

Trauma impacts the functioning of the brain in two major ways: first, the normal processing of memories is blocked, and second, core beliefs in the "implicit self" are shattered, resulting in a loss of one's sense of security. The first of these is treated in this article.

Raw sensory data arrive in the amygdala, ${ }^{18}$ from where they are quickly sent to the hippocampus for processing and storage as a biographical record in narrative memory. ${ }^{19}$ Memory consists of mental constructs (or schema) which a person uses to make sense from an experience. ${ }^{20}$ Processing requires assigning the memory to an existing (or new) schema, which is conscious and can usually be recalled. Only after an experience has been placed into a meaningful context can it be interpreted..$^{21}$ But during situations of trauma, memories are not properly processed. There are two views as to why this occurs: the first suggests there is a lack of schema to process the trauma memory, ${ }^{22}$ and the second refers to "hippocampal atrophy". 23

The early view believed that frightening or novel experiences may not easily fit into existing schema and thus may resist integration. The memories

\footnotetext{
18 The amygdala and hippocampus are parts of the brain which act synergistically to form long-term memories of significantly-emotional events.

19 Richard J. McNally, Remembering Trauma (Cambridge, MA: Harvard Univ. Press, 2003), 141.

20 Bessel A. van der Kolk and Onno van der Hart, "The Intrusive Past: The Flexibility of Memory and the Engraving of Trauma," in Trauma. Explorations in Memory (ed. Cathy Caruth; Baltimore: John Hopkins Univ. Press, 1995), 160.

21 Daniel L. Schacter, "Implicit Memory: History and Current Status," Journal of Experimental Psychology: Learning Memory, and Cognition, 13 (1987):501-518.

22 Pierre Janet, Les médications psychologiques. 3 vols. (Paris: Société, 1919-25 reprint 1984).

23 E.g. John W. Newcomer, Gregg Selke, Angela K. Melson, Tamara Hershey, Suzanne Craft, Katherine Richards, and Arny L. Alderson, "Decreased memory performance in healthy humans induced by stress level cortisol treatment," Archives of General Psychiatry, 56 (1999):527-533.
} 
then become dissociated, to return intrusively as fragmented sensory images. ${ }^{24}$ For healing to occur, the trauma memories must become integrated with existing schema, and be transformed into language.

The "hippocampal atrophy" hypothesis proposes that during trauma, the adrenal glands over-secrete a hormone (GC) resulting in hyperactivity in the amygdala and the dysfunction of the hippocampus. ${ }^{25}$ Consequently, new sensory data are not processed and stored in biographical memory, but remain in the amygdala as raw, noxious emotions and sensory fragments. ${ }^{26}$ The memory is not conscious and cannot be voluntarily recalled, but is evoked automatically and involuntarily (as a "flashback") in conditions reminiscent of the original trauma event. The sensory material, predominantly visual, is experienced as if happening in the present. It is often impossible to articulate this trauma memory verbally. ${ }^{27}$ As a result, subconscious memories control behaviour, causing the sufferer to have emotional problems in relating to stimuli in the environment (including people). ${ }^{28}$

\section{Approaches to trauma healing using cognitive psychotherapy}

Clearly the intrusive, negative memories need to be transformed into a benign form. Cognitive therapists seek to do this by reconstructing the trauma memory, removing the associated negative emotion, and integrating it into the person's personal biography as an event in the past. Two theories suggest different ways to transform the trauma memory. Emotional processing theory emphasizes the importance of incorporating "non-confirming" information into the traumamemory. ${ }^{29}$ Dual Representation theory ${ }^{30}$ suggests that memories which are situationally-accessible (often comprising powerful visual images which provoke excessive fear) must be converted into verbally-accessible memories (which have meaning). ${ }^{31}$ The method is to associate new, positive images with

24 Van der Kolk and van der Hart, "The Intrusive Past," 176.

25 McNally, Remembering Trauma, 137.

26 Edward Hug, "A Neuroscience perspective on psychodrama" in Psychodrama. Advances in Theory and Practice (eds. Clark Baim, Jorge Burmeister and Manuela Maciel; London: Routledge, 2007), 232.

27 Elizabeth A. Brett and Robert Ostroff, "Imagery and Post-Traumatic Stress Disorder: An Overview," American Journal of Psychiatry, 142 (1985):417-424.

28 See van der Kolk and van der Hart, "The Intrusive Past," 164.

29 For example, Van der Kolk and van der Hart ("The Intrusive Past," 178) give the example of a Holocaust survivor who was encouraged to imagine a flower growing in Auschwitz.

30 Chris R. Brewin and Emily A. Holmes, "Psychological theories of posttraumatic stress disorder," Clinical Psychology Review, 23 (2003):356.

31 Ruth Poser, "No Words", 37. 
the trauma so that the original negative memories are not activated. ${ }^{32}$ These concepts will be incorporated into the "healing poems of lament" which will be composed in the empirical study. Such poems fall within the bigger study of verbal approaches to the healing of trauma.

\section{VERBAL APPROACHES TO HEALING TRAUMA}

The connection between literature and trauma is two-fold: first existing literature can help trauma survivors, and second, trauma survivors need to create their own literature (be it a narrative or poem) to gain control over the trauma. ${ }^{33}$ The first approach recognizes that sufferers "want to tell their stories ... but they are often unable to do so because they lack words for their experiences". ${ }^{34}$ However, there are texts available which encode trauma and witness to trauma, ${ }^{35}$ and thereby facilitate recovery and resilience. ${ }^{36}$ Such texts assist victims to articulate their traumatic experience before others and God, and thus have a "restorative capacity", 37 For example, 2 Sam 13 (the rape of Tamar) can help survivors of domestic violence, ${ }^{38}$ in that Tamar preserves her "agency", and demonstrates a

32 Chris R. Brewin, "A cognitive neuroscience account of posttraumatic stress disorder and its treatment," Behaviour Research and Therapy, 39 (2001):376. See also Brewin and Holmes, "Psychological Theories," 357, 360.

33 Michael Medley, "A Role for English Language Teachers in Trauma Healing", TESOL Journal, 3/1 (2012):118 encourages those teaching traumatised children to include opportunity for them to express themselves creatively.

34 Poser, "No Words," 30. Trauma impairs the functioning of the Broca's area of the left cerebral cortex of the brain, the part that takes feelings and puts them into words. See Scott L. Rausch, Bessel A. van der Kolk, Rita E. Fisler, Scott P. Orr, Nathaniel M. Alpert, Cary R. Savage, Alan J. Fischman, Michael A. Jenike, and Roger K. Pitman, "A symptom provocation study of posttraumatic stress disorder using positron emission tomography and script driven imagery," Archives of General Psychiatry, 53 (1996):380-387.

35 Literature possesses "witnessing" power that facilitates the healing process (Jennifer A. Rahim, "Reflections on Contemporary Christian Theologies of Suffering and the Value of Trauma Literature," (MA thesis, Toronto School of Theology, 2016), 90).

36 Frechette and Boase, "Defining 'Trauma' as a Useful Lens," 10-11.

37 Brent A. Strawn, "Trauma, Psalmic Disclosure, and Authentic Happiness" in Bible through the lens of Trauma (eds. Christopher Frechette and Elizabeth Boase; Atlanta: SBL, 2016).

38 Gerald O. West, "Between Text and Trauma: Reading Job with people living with HIV" in Bible through the lens of Trauma, (eds. Christopher Frechette and Elizabeth Boase; Atlanta: SBL, 2016), 216. 
"capacity for resistance, survival, and recovery", 39 all of which can encourage victims in their own situations.

The second approach to using literature as part of trauma therapy is to create one's own trauma narrative. ${ }^{40}$ According to Judith Herman, ${ }^{41}$ a trauma therapist, this gives the victim a voice, the first requirement of healing. Moreover, the reconstruction of the trauma story allows the memory to be reclaimed, along with the associated emotions. This is essential if the sufferer is to gain mastery over the trauma: the emotions must be brought to conscious awareness and expressed in language. ${ }^{42}$

Creating the trauma account not only serves to restore agency to the victim, but it also reduces the sense of isolation, ${ }^{43}$ providing opportunity to be heard by someone. ${ }^{44}$ During trauma the "implicit self" collapses, resulting in the person no longer feeling safe nor able to trust. ${ }^{45}$ Thus, the safe and supportive presence of others as witnesses and dialogue partners is crucial for advancing the process of reinterpreting the traumatic experience. ${ }^{46}$ Indeed, "Validation is a vital component. Opportunity to articulate one's experience and to have it validated by those who understand are important elements in the building of resilience and in the healing of trauma." 47 Moreover, "telling a story" in a safe environment can impact the biochemical balance of the body, and thus reduce or reverse negative behavioural responses. ${ }^{48}$ However, this approach to healing takes time and is never final nor complete. Nevertheless, helping the survivor to shift the traumatic

39 Juliana L. Claassens, "Trauma and Recovery: A New Hermeneutical Framework for the Rape of Tamar (2 Samuel 13)" in Bible through the lens of Trauma, (eds. Christopher Frechette and Elizabeth Boase; Atlanta: SBL, 2016), 177-192.

40 Eve-Marie Becker, “'Trauma Studies' and Exegesis. Challenges, Limits and Prospects" in Trauma and Traumatization in Individual and Collective Dimensions. Insights from Biblical studies and Beyond (eds. Eve-Marie Becker, Jan Dochhorn, and Else K. Holt; Göttingen: Vandenhoeck and Ruprecht, 2014), 21.

41 Herman, Trauma and Recovery, 155, 175.

42 Herman, Trauma and Recovery, 177.

43 Martin Symonds, "Victim Responses to Terror: Understanding and Treatment" in Victims of Terrorism (eds. Frank M. Ochberg and D. Soskis; Boulder, CO: Westview, 1982), 95-103.

44 Jon G. Allen, Coping with Trauma. Hope through understanding (Washington: American Psychiatric Publishing, 2005), 252, 266.

45 Allan Schore, "Right-Brain Affect Regulation," in The Healing Power of Emotion (eds. Diana Fosha, Daniel J. Siegel, and Marion F. Solomon; New York: Norton, 2009), 126, 144.

46 Frechette and Boase, "Defining 'Trauma' as a Useful Lens," 7.

47 Gerald O. West, "Between Text and Trauma: Reading Job with people living with HIV" in Bible through the lens of Trauma (eds. Christopher Frechette and Elizabeth Boase; Atlanta: SBL, 2016), 220, 225.

48 Herman, Trauma and Recovery, 183, 195. 
memory to the past enables him/her to give attention to the present and the future, with hope.

\section{The value of poetry (including psalms) in healing memories}

In the past, narrative has been used to help sufferers process their trauma, ${ }^{49}$ but "Poetry can also advance the process of constructing meaning related to traumatic events." 50 Indeed, poetry has several unique features which make it particularly suitable to help trauma sufferers. First, the construction of a poem mimics the way a trauma memory is held. Unlike narrative, which must be processed in a linear fashion, a poem is comprehended as a whole. Trauma sufferers have a collection of feelings, pictures, and ideas which often cannot be sorted into a logical order. But in a poem, sufferers can express their mixture of feelings without needing to be coherent. As Jones comments: "The cadence of poetry and its associative structure invite the voice of the shattered to unfold in its space." 51

Many psalms of lament "reveal a disturbed state of illogical thinking", ${ }^{2}$ and consequently reading such psalms (and using them to compose their own poems) can be particularly helpful for trauma sufferers. As poetry (like music) is processed in the right brain, ${ }^{53}$ a person can respond to, and create poems, even when the language centre (the Broca's area in the left brain) is disturbed. Poetry is very appropriate as a means for sufferers to tell their stories, for what is important is that the trauma account includes the triggers of the fear (shapes, colours, etc.) rather than be detailed and well organised (as in a narrative). ${ }^{54}$ Poetry, being image-based, ${ }^{55}$ is well able to include such triggers.

Indeed, through its use of metonymic images, a poem can bring to consciousness the whole trauma experience through a single word (such as

49 E.g. Radikobo Ntsimane, "Why should I tell my story? Culture and Gender in Oral History" in Oral History in a Wounded Country. Interactive Interviewing in South Africa (eds. Philippe Denis and Radikobo Ntsimane; Scottsville: UKZN Press, 2008).

50 Frechette and Boase, "Defining 'Trauma' as a Useful Lens," 6-7.

51 Serene Jones, "Soul Anatomy: Calvin's Commentary on the Psalms" in Psalms in Community. Jewish and Christian Textual, Liturgical, and Artistic Traditions (eds. Harold W. Attridge and Margot E. Fassler; Atlanta: SBL, 2003), 273-274. She emphasises that poetry can be very helpful as it "[does not] assume narrative closure". 52 Louis Stulman, "Reflections on the Prose Sermons in the Book of Jeremiah."

53 Walter R. Johnson, The Idea of Lyric: Lyric modes in ancient and modern poetry (Berkeley: Univ. of California, 1982), 714 refers to the musicality of psalms (as a result of their rhythm, meter, alliteration, assonance, and other sonorous features).

54 Brewin, "A cognitive neuroscience account," 388-389.

55 David R. Johnson, "Creative Therapies" in Effective Treatments for PTSD (ed. E.B. Foa; New York: Guildford, 2000), 305. 
"headlights" or "fire"). ${ }^{56}$ By exercising the imagination, ${ }^{57}$ the sufferer can also find a new vibrant metaphor which speaks into his/her situation and will be more strongly associated with the trigger than the former troublesome memory. The choice of the new image may appear ambiguous, the visual picture retaining a "private mystery," 58 but it still can significantly change perception. ${ }^{59}$ Even if the sufferer cannot explain in words why it is meaningful, at the unconscious level new possibilities will arise, ${ }^{60}$ thereby creating a new reality. ${ }^{61}$ Dobbs-Allsopp ${ }^{62}$ notes that the poetry of the psalms also has this capacity: "to inspire us to new ways of seeing and imagining, even to new ways of thinking."

Poetry also contributes significantly to trauma-healing through its use of patterns. Poetic structures (such as parallelism, chiasm, and inclusio, as well as a regular rhythm) provide an "anticipation" of what is to come. When the "anticipation" is not fulfilled, through an interruption in the established pattern, ${ }^{63}$ a certain tension (or "uncertainty") results for the hearer until the meter is restored. ${ }^{64}$ The "moderate stress" created by such a break in the pattern contributes to the development of healing neurons. ${ }^{65}$ Indeed, the poet's play with patterns has "transforming power". 66 "Free verse" can be even more stimulating, with the hearer having to "reach out for what cannot be anticipated". ${ }^{67}$ These

56 Craig C. Broyles, The Conflict of Faith and Experience in the Psalms. A FormCritical and Theological Study (Sheffield: JSOT Press, 1989), 17.

57 Imagination by definition is the "making of images" (Terence Hawkes, Metaphor (London: Methuen, 1972), 42-43).

58 Sheldon Sacks, On Metaphor (Chicago: Univ. of Chicago, 1979), 109.

59 Paul Ricoeur, The Rule of Metaphor (Toronto: Univ. of Toronto Press, 1975-79), 190.

60 George B. Caird, The Language and Imagery of the Bible (London: Duckworth, 1980), 57-58.

61 Hawkes, Metaphor, 63.

62 F.W. Dobbs-Allsopp, "Psalms and Lyric Verse," n.p. [cited 22 October 2019]. Online: https://www.academia.edu/3769980/Psalms_and_Lyric_Verse?email_work_ card=thumbnail

63 For example, a change in rhythm may be used by the poet to indicate focus.

64 Reuben Tsur, Poetic Rhythm: Structure and Performance (Sussex: Academic Press, 2012), 24.

65 Louis L. Cozolino, The neuroscience of psychotherapy (New York: WW Norton, 2002), 24. This is further discussed in section 4.2.

66 Wilson Yates, "Intersections of Art and Religion," Arts: The Arts in Religious and Theological Studies 10/1(1998):17-24.

67 Cathy Caruth, Trauma. Explorations in Memory (Baltimore: John Hopkins University Press, 2016), 26 notes that Mallarmé, by introducing "free verse" into French poetry, heightened the hearer's participation in the text. 
patterns, and the lack of fulfilment (or knowledge) of "the anticipation", may not be consciously processed, but are nevertheless sub-consciously detected. ${ }^{68}$

Further, research has shown that both poetry and music stimulate the part of the brain associated with reward and emotion. ${ }^{69}$ A person senses pleasure when he/she "habitates" a poem (or psalm) ${ }^{70}$ For this to happen, the reader needs to actively engage with the poem, ${ }^{71}$ and try to enter into the poet's universe, "invading and occupying [the text]". ${ }^{72}$ Culler $^{73}$ emphasises the need for the reader "to linger in the various patterns or metaphors in the poem", thus making its reading "an event". The poet, Gregory Orr, ${ }^{74}$ remembers his first interaction with the patterns of a lyrical poem, and asserts that it was "a revelatory experience of hope and pleasure".

Biblical poetry (as in psalms) has another significant advantage over narrative for promoting healing. The right brain, which is active in the composition of poetry, is associated with religious experiences. ${ }^{75}$ Thus the exercise of studying biblical psalms and composing one's own lament can be expected to promote healing of the soul. ${ }^{76}$

68 Awel Vaughan-Evans, Robat Trefor, Llion Jones, Peredur Lynch, Manon W. Jones, and Guillaume Thierry, "Implicit Detection of Poetic Harmony by the Naïve Brain", Frontiers in Psychology (2016).

69 See Anne J. Blood and Robert J. Zatorre, "Intensely pleasurable responses to music correlate with activity in brain regions implicated in reward and emotion", Proc Natl Acad Sci USA, 98 (2001) for the relationship between listening to music and brain activity. See Adam Zeman, Fraser Milton, Alicia Smith, and Rick Rylance, "By Heart An fMRI Study of Brain Activation by Poetry and Prose," Journal of Consciousness Studies, 20/ 9-10 (2015):132-158 for the relationship between the reading of poetry and brain activity. The latter found that poetry triggers different parts of the brain from that for prose, and this stimulation gives a sense of psychological reward.

70 Daniel J. Estes, "The Hermeneutics of Biblical Lyric Poetry," Bibliotheca Sacra 152, 608 (1995):426-428 suggests that to "habitate" a poem, it should be read aloud, read reflectively, and read imaginatively.

71 "Poetry cannot be grasped from the outside by the passive bystander" (Estes, "The Hermeneutics of Biblical Lyric Poetry," 427).

72 Jonathan Culler, "Why Lyric?," PMLA 123/1 (2008):205.

73 Jonathan Culler, Literary Theory: A very short introduction (Oxford University Press, 2011), 73.

${ }^{74}$ Gregory Orr, Poetry as Survival (Athens, GA: The University of Georgia Press, 2002), 6-8.

75 Edward Hug, "A Neuroscience perspective on psychodrama,” 234.

76 See Emily Lyon, “The Spiritual Implications of Interpersonal Abuse: Speaking of the Soul," Pastoral Psychology, 59 (2010):238. 
From a study of biblical laments, Villanueva ${ }^{77}$ lists three criteria that are important if the lamenter is to have the "certainty of being heard", a major condition for healing. ${ }^{78}$ The first of these is "the gift of speech" (what Herman calls the recovery of agency), the second is the realisation that the "enemy" will receive justice, and the third is "the discovery of God" (which Herman refers to as "factors enabling the person to reconnect with life going forward"). In this regard, psalms of lament are particularly appropriate as they satisfy all three criteria. ${ }^{79}$ The poems composed in the empirical study, modelled on psalms of lament, will also give participants the certainty of being heard.

Biblical laments have considerable value as "survivor literature" in that they were articulated by those in the midst of distress and so give sufferers a voice to articulate their pain. ${ }^{80}$ Emotions are openly expressed, facilitating for the reader an attitude of protest rather than capitulation. ${ }^{81}$ Further, as they are addressed to God, the lamenter has a sense of having handed over the problem to someone "big enough" to respond in some positive way. ${ }^{82}$ This added spiritual dimension sets psalms apart as a unique vessel for expressing pain.

\section{$2 \quad$ Composing a lament poem as a means of healing}

Several researchers ${ }^{83}$ are now showing that the brain is able to heal itself as a result of its "neural plasticity". ${ }^{84}$ Under normal conditions, the right hemisphere

77 Federico G. Villanueva, The Uncertainty of a Hearing. A study of the sudden change of mood in the psalms of lament (Leiden: Brill, 2008), 25.

78 Philippe Denis, "Storytelling and Healing" in A Journey towards Healing: Stories of People with Multiple Woundedness in Kwazulu-Natal (eds. Denis Philippe, Scott Houser, and Radikobo Ntsimane; Pietermaritzburg: Cluster, 2011), 11 notes that: "Once a safe space has been created, two other key processes are at work: the elaboration of the painful experience and its validation through empathetic listening."

79 Unlike many trauma-healing approaches, biblical laments give space for the sufferer to experience a sense of justice, an essential aspect if he/she is to be free from the pain caused by others. By handing over retribution to God, the lamenter can move forward with a sense of peace that "right has been done, or will be done".

80 Ken Stone, "Safer texts: Reading Biblical laments in the age of AIDS", Theology and Sexuality, 10 (1999):20-21.

81 Todd Linafelt, "Surviving Lamentations (one more time)" in Lamentations in Ancient and Contemporary Cultural Contexts (eds. Nancy C. Lee and Carleen Mandolfo; Atlanta: SBL, 2008), 62.

82 Claus Westermann, Praise and Lament in the Psalms, (USA: John Knox Press, 1981), 80-81.

83 E.g. Norman Doidge, The brain that changes itself. Stories of personal triumph from the frontiers of brain science (New York: Penguin Books, 2007).

84 Joseph LeDoux, "Emotions: How I've looked for them in the brain" in Neuroscience and the person (eds. Robert J. Russell, Nancey Murphy, Theo C. Meyering and Michael A. Arbib; Vatican City State: Vatican Observatory, 2002), 8, 41-44. 
releases neuro-hormones which promote the constant development of new neural stem-cells in the hippocampus. These can grow and differentiate into the various kinds of cells needed by the nervous system. Following trauma, when hippocampal cells have been destroyed, new cells can be generated, to facilitate the proper processing of memories. ${ }^{85}$ To promote this development, an optimum level of stimulation is required. ${ }^{86}$ Cozolino $^{87}$ defines this as "moderate levels of stress such as that involved in new learning", particularly when the learning involves creative activities. ${ }^{88}$ However, the learning must happen in a positive interpersonal environment. ${ }^{89}$

I would suggest that participation in lament activity (as in the workshops of this study) can satisfy the conditions required for biological and social healing. First, it provides "a moderate level of stress" as the participant learns something new. Second, as the activity involves the use of the imagination (composing a poem and thinking of new metaphors to describe one's experience), it should be particularly helpful. Third, a positive interpersonal environment is achieved by performing one's lament before fellow sufferers.

\section{E EMPIRICAL STUDY}

Three sectoral groups were invited to participate in a "lament workshop" during which participants studied Psalms 3 and 13, noted their salient features, and then composed and performed their own laments (individual and communal), coming out of their experience but using the biblical laments as idea-stimulators. The three groups were ten young Zulu women (part of an AIDS support group), nine Zulu youth (three men and six women) from the LGBT community, and three refugees (a Zimbabwean woman and two Burundian men). The study took place in Pietermaritzburg, South Africa, each group having its own workshop of two hours' duration.

Psalms 3 and 13 are both brief, but contain some important elements of personal lament. For both psalms, the participants studied the Hebrew text and various translations in Zulu and English. They noted repetitions (as highlighted below in grey or with bold font), metaphors, mood (and changes in mood), the use of rhetorical questions, petitions, complaints (against God or the enemy), and expressions of trust, praise, or hope. Portions of the analysis for the two psalms follow, highlighting relevant features.

\footnotetext{
85 LeDoux, "Emotions," 56.

86 Hug, "A Neuroscience perspective on psychodrama", 232.

87 Cozolino, The neuroscience of psychotherapy, 24.

88 The malfunctioning of the right brain leads to the person not being able to consider different possible solutions. Intentional use of the imagination can counter this.

89 Herman, Trauma and Recovery, 176-177.
} 


\section{Brief analysis of poetical features in Psalm 390}

1 LORD, how my enemies have become many! Many are the ones rising up against me.

2 Many are the ones saying of my soul: "There is no salvation for him in God."

3 But, LORD, you are a shield about me, my glory, and the one lifting my head.

4 I call with my voice to the LORD, and He answers me from his holy mountain.

5 I lie down, and I sleep; I awake, for the LORD sustains me.

6 I am not afraid from ten thousands of people, who on every side have set their minds against me.

$7 \quad$ Arise, LORD; save me, my God; for you chastise all my enemies on the cheek, the teeth of the wicked you have shattered.

8 To the LORD salvation; on your people your blessing.

For the purposes of this study, focus was on the use of poetry to express emotion. Thus the participants noted the major poetic features evident in the Hebrew:

Lexical repetitions: The repetition of "many" in vv.1, 2 and 6 (implied) is significant, emphasising the enormity of the problem to the lamenter.

Mood swings: There is a sudden change in mood in v.3 (marked by the adversative waw, 'but'). A mood of fear changes to one of faith (vv.3-6), suggesting that help has already been experienced or that, if the situation has not yet changed, assurance has been given that deliverance will come. Although the change of mood here is from complaint to praise, participants noted that in other psalms (e.g. Ps 28) there is a mixture of emotion, and the ending is not necessarily praise. ${ }^{91}$ Consequently, participants were encouraged to be honest about their emotions, regardless of whether they were "positive" or "negative".

Inclusion of direct speech: The use of direct speech in v.2 makes the taunt of the enemies more vivid.

Imagery: Verse 1 has the image of an enemy "rising" against the lamenter. This threat is countered by strong pictures of security (a "shield" providing protection, and the person able to sleep peacefully despite being surrounded by

90 The translation used in the workshop is the author's, compiled from various English translations, seeking to use simple language and to maintain the repetitions in the Hebrew.

91 As Villanueva (The Uncertainty of a Hearing, 256) points out, "The psalms that show an alternation between lament and praise give a more realistic perspective of restoration being a process, not always immediate." 
enemies). In v.7 there is a vivid image of the enemies being struck in the face, so that even their teeth are broken. The punishment matches the offence (taunting behaviour), bringing to an end their mocking speech.

These poetic devices were used to express complaint (vv.1-2), trust (vv.36), petition (v.7a-b), a request for justice (v.7c-d), and a wish for blessing (v.8b). These comprise the basic elements of biblical lament, and are also seen in the study of Ps 13 (with the exclusion of a "wish for blessing").

\section{Brief analysis of poetical features in Psalm $13^{92}$}

1 How much longer, LORD, will you forget about me? Will it be forever?

How long will you hide?

2 How long must I be confused and miserable all day?

How long will my enemies keep beating me down?

3 Please listen, LORD God, and answer my prayers.

Make my eyes sparkle again, or else I will fall into the sleep of death. ${ }^{93}$

4 My enemies will say, "Now we've won!"94

They will be greatly pleased when I am defeated. ${ }^{95}$

5 But I trust your love, ${ }^{96}$ and I feel like celebrating, because you rescued me.

6 You have been good to me, LoRD, and I will sing about you.

Lexical repetitions: The four-fold repetition of "how long" (vv.1-2), ${ }^{97}$ framed by rhetorical questions functioning as complaints, highlights the lamenter's frustration.

$92 \mathrm{CEV}$ is given here as the base translation. Some amendments were made for the workshop participants, as indicated in footnotes.

93 Verse 3 for the workshop participants read: Show me what's going on so that I don't live as one who is far from you, spiritually dead.

94 Mitchell Dahood, Psalms I (1-50), Anchor Bible (New York: Doubleday, 1966), 77 asserts that the Hebrew may mean "Be high over me" or "rejoice over me". He argues that parallelism supports the latter. The CEV and the workshop translation (in the next footnote) incorporate both ideas.

95 Verse 4 for the workshop participants read: Don't let it happen that my enemies say, "We've won!" and have a party because I'm falling. Dahood, Psalms I, 77-78 claims that the final verb הַמָּות (hamot 'stumble') has the connotation here of falling, or stumbling, into the jaws of death, Mot being the god of death. The word-play supports this idea.

96 "But" is in the Hebrew, and thus the CEV was amended for the workshop participants, to help them see the change of mood.

97 The first occurrence of 'How long' seems to be an incomplete sentence in Hebrew. Allen Ross, A Commentary on the Psalms (Vol 1): 1-41 (Grand Rapids: Kregel, 2011), 
"Enemies" are mentioned as part of the problem in v.2b, and the topic is repeated in v.4 with a request for justice against them. The repetition of "enemies" as well as the direct quotation of their words suggests that they continue to harass the lamenter, in his mind anyway. The petitioner has a strong need for justice to be executed on his behalf.

Mood swings: There is a change in mood from complaint to petition in vv.3-4, and then to affirmation of trust in vv.5-6. ${ }^{98}$ The change in mood at v.5 is highlighted by the adversative waw, indicating that something new is beginning. ${ }^{99}$ As in Ps 3, it is at the palmist's lowest point (v.4) that there is a movement towards trust and hope (v.5). Mays ${ }^{100}$ notices that these changes in mood correlate with mention of the enemy.

Inclusion of direct speech: The use of direct speech in v.4 adds to the rhetorical force and immediacy of the poem.

Imagery and language choice: The first two verses pile up the lamenter's sense of complaint: apart from the four-fold accusatory "how long", "you hide", "you forget", words such as "confused", "miserable", and "beating me down" paint a dismal picture.

The petitions in the Hebrew (vv.3-4) include "enlighten my eyes lest I sleep the death". Dahood ${ }^{101}$ argues for a two-fold interpretation of "enlighten my eyes", viz. to restore health and "to see the light" spiritually and so enjoy immortality. He also argues for a two-fold meaning for "[avert] the sleep of death", referring to both physical and spiritual death. In the workshop, I gave the translation of avoiding spiritual death, to help participants recognise that it is not only physical death that is referred. (See footnote 95. )

Using these ideas of the form and content of biblical laments, the participants then composed their own personal laments.

\section{Zulu pain-bearers compose their own laments}

The participants were all keen to express themselves and give voice to their pain. They were encouraged to use language that spoke of their experiences and

\footnotetext{
364 notes that breaking off speech midsentence is a poetic device used to express extreme emotion.

98 Broyles (The Conflict of Faith and Experience in the Psalms, 186) notes that there is "a movement from protest to petition to praise". He asserts that affirmations of faith (the move towards praise) are attempts by the lamenter to motivate YHWH to action. 99 Claus Westermann, The Living Psalms (Trans. J.R. Porter. Edinburgh: T\&T Clark, 1989), 71-72.

100 James L. Mays, Psalms. Interpretation commentaries (Louisville: John Knox Press, 1994), 66.

101 Dahood, Psalms I, 78.
} 
conveyed their personal emotions, and to use images that were meaningful to them. They were also encouraged to recognize that "enemies" in the psalms can refer to whoever has caused them pain.102 For the individual laments, the compositions were written and not shared (except with the researcher). Below are three examples, selected because they incorporate several of the typical formal elements of biblical laments (viz. lexical repetitions, mood swings, use of rhetorical questions and colourful imagery) to express complaint, petition, and a request for justice, and an affirmation of trust.

In the first example, a Zimbabwean woman refugee complains to God, using rhetorical questions (shaded in the text below), then petitions God (in italics) and then shows trust as she remembers past experiences with God (indicated by bold text). There are further petitions interspersed with statements of trust. Mood swings reveal the tension between her experience and her expectations of how God should act in her situation. In terms of mimicking the form of biblical lament, one notes also the lexical repetition (e.g. "justice", "bad management") as well as her request for justice ("same pain... backfire on AR").

For how long, God, will you allow the enemy to do whatever he wants towards my life? For how long, God, will you allow the enemy to attack my family spiritually?

Please, dear God, I know you are my protector. Please protect me and my family from the evil schemes of Satan. Please, Lord, kindly heal me and my family spiritually and physically, from all sickness. With the blood of Jesus and with the stripes of Jesus, I know that I and my family will be healed.

Lord, please take away the powers of my enemies, and the bad management of AR who took away my job whilst I was pregnant. May justice prevail over my situation because you are a God of truth and justice. Lord, may the same pain that Ifelt after losing my job, backfire on AR for his bad management.

Lord, you are full of grace, mercy and compassion. You are always there for me when I am down or sad. Heal my broken heart and spirit within me and let your Holy Spirit fill me.

In the second example (below), a young Zulu woman from the LGBT support group begins her lament with a long complaint to God utilizing a string of rhetorical questions (indicated by shaded text). It is clear that she has experienced significant hurt and disillusionment, and she is open about expressing it to God. However, one notes mood swings, in that the tirade of complaint is interrupted with a brief statement of trust (bold text) before a barb

102 Patrick D. Miller, Interpreting the Psalms (Philadelphia: Fortress Press, 1986), 5051 asserts that "the enemies" are "whoever the enemies are for the singer of the psalm". 
of complaint, and then ending on a note of hope and trust. Her poem also shows lexical repetition (e.g. "why ...?" and particularly "you said ..."). Although she does not include a request for justice to be served on the perpetrator (because the perpetrator here is God, ${ }^{103}$ as the first line indicates) and does not use imagery, her lament does include a fair number of elements typical of lament psalms.

Why? Why, Lord? Why did you let this happen to me?

The questions I have:

Why did you let my parents die? I thought I was going to be there for them all the time.

You said in your word, You said in your word that nothing bad would happen to me, if I stayed with you. But why, Lord, why?

What am I supposed to do now, Lord?

You said you would never forsake me, Lord.

You said you would protect me.

You said you would stand with me.

It's OK. He will not disappoint. He will stand with me,

Even though it's happening right now.

Bad things might happen. But he's still here. He's still my Lord.

The third example is that of a young Zulu woman, a member of an AIDSsupport-group. Her poem shows mood swings between complaint (shaded text) and statements of trust (in bold text). Although her lament is mainly complaint, there is a "break in" of trust ("I know ... I have to wait"), followed by further complaint ("But it's hard") and then concluding with a statement of trust ("you are my light").

She also uses some powerful metaphorical language in lines 4 and 5. The metaphor of others "playing" her, and her being acted upon so that she is no longer able to function properly ("like a car that won't start") indicates her sense of being abused, and yet the fact that she is now telling her side of the story, having "a voice", is the first step towards her healing. ${ }^{104}$

There is no direct petition in this lament, although the rhetorical question ("Didn't they say that you listen when you are called?") is a veiled petition. Also there is no request for justice against the perpetrator, as "the enemy" is God. However, one does note lexical repetitions ("But ..." and "till when ...?") thus the poem includes a good number of the features typical of biblical lament.

103 The biblical laments often include petition for justice against the perpetrator, except when the major perpetrator is seen to be God.

104 Herman, Trauma and Healing, 134. 
My Lord, I sometimes hesitate that you are there,

Lord, till when will I suffer?

Every time I try to put things together ...

For how long will people play me?

They make me like a car that won't start, a useless one. Till when?

Life is not coming together.

And you are there, just looking.

Didn't they say that you listen when you are called?

But you are taking long to answer,

But ... till when?

Till when, my Lord - me leaving my poverty?

Others do get help, but me - I'm not.

I know my Lord, I have to wait,

But it's hard.

\section{I will stay in the hope,} And you are my light.

From these examples and the others in the study, it appears that the compositions generally start with complaint and end on a note of hope. ${ }^{105}$ What is of interest is that most of the poems include the basic elements of biblical psalms, either deliberately imitating the form of biblical lament or because such elements are intuitively part of the human response to trauma: complaint, request for relief, a need for justice to be served, and hope that things will get better.

Despite the significant tension apparent in the laments, the composers seem to be searching in their honesty for a new reality (either in their physical situation or their interior situation), rather than submitting "in defeat" or simply accepting "God is big and can do what God likes". In their honest grappling with the gap between their experience and what they would like the situation to be, and their confusion of how a supernatural, caring God fits into this gap, their moods swing, but reflect the reality of their internal life. However, the fact that they were able to verbalise their pain and confusion is significant.

\section{F CONCLUSIONS}

Much in the theory of trauma therapy supports the possibility that the very act of composing (and then performing) lament can be helpful in contributing to healing for those bearing the pain of some trauma. The empirical compositions also satisfy Villanueva's three criteria in a lament psalm that give the performer the sense of "being heard". First, the sufferer regains a voice, and can tell the story from her perspective. Second, there is the realisation that the perpetrator /enemy will receive justice (as happens in the first example when the speaker asks God to "pay back AR"). All of the empirical laments also include the third

105 This is possibly the result of participants coming from "God-fearing" communities. 
criterion, viz. connection with life going forward. They have remembrances of God and/or flashes of hope. Thus, based on both Herman's steps of healing and Villanueva's criteria, it is probable that the participants did gain from the experience of lamenting - socially, physically, and spiritually. Their confidence in themselves improved, they felt understood by others, and they had been able to bring their most painful experiences to God. There is also the possibility that the creative exercise contributed to physical healing in the brain. Thus lament can play a part in the post-trauma healing process, helping sufferers to improve all their relationships: with themselves, with others, and with God.

\section{BIBLIOGRAPHY}

Allen, Jon G. Coping with Trauma. Hope through understanding. Washington: American Psychiatric Publishing, 2005.

Becker, Eve-Marie. "Trauma Studies and Exegesis. Challenges, Limits and Prospects." Pages 15-29 in Trauma and Traumatization in Individual and Collective Dimensions. Insights from Biblical studies and Beyond. Edited by Eve-Marie Becker, Jan Dochhorn, and Else K. Holt, Göttingen: Vandenhoeck and Ruprecht, 2014. https://doi.org/10.13109/9783666536168.15.

Blood, Anne J. and Zatorre, Robert J. "Intensely pleasurable responses to music correlate with activity in brain regions implicated in reward and emotion", Proc Natl Acad Sci USA, 98 (2001):11818-11823. https://doi.org/10.1073/pnas. 191355898.

Brett, Elizabeth A. and Ostroff, Robert. "Imagery and Post-Traumatic Stress Disorder: An Overview." American Journal of Psychiatry, 142 (1985):417-424. https://doi. org/10.1176/ajp.142.4.417.

Brewin, Chris R. "A cognitive neuroscience account of posttraumatic stress disorder and its treatment." Behaviour Research and Therapy, 39 (2001):373-393. https://doi.org/10.1016/S0005-7967(00)00087-5.

Brewin, Chris R. and Emily A. Holmes. "Psychological theories of posttraumatic stress disorder." Clinical Psychology Review, 23 (2003):339-376. https://doi.org/10. 1016/S0272-7358(03)00033-3.

Broyles, Craig C. The Conflict of Faith and Experience in the Psalms. A Form-Critical and Theological Study. Sheffield: JSOT Press, 1989.

Caird, George B. The Language and Imagery of the Bible. London: Duckworth, 1980.

Caruth, Cathy. Trauma. Explorations in Memory. Baltimore: John Hopkins University Press, 2016.

Claassens, L. J. "Trauma and Recovery: A New Hermeneutical Framework for the Rape of Tamar (2 Samuel 13)." Pages 177-192 in Bible through the lens of Trauma. Edited by Christopher Frechette and Elizabeth Boase, Atlanta: SBL, 2016. https://doi.org/10.2307/j.ctt1h1htfd.13.

Claassens, L.J. "Preaching the Pentateuch: reading Jeremiah's sermons through the lens of cultural trauma", Scriptura, 116/2 (2017). Online version: http://doi.org /10.7833/116-2-1313.

Cozolino, Louis L. The neuroscience of psychotherapy. New York: WW Norton, 2002.

Craig, Eleanor C. "“Un Imaginable Boundaries': Performativity, Theology, and the Study of Trauma.” D.Th thesis, Harvard Divinity School, 2017. 
904 Dickie, "Healing of Trauma Memories," OTE 32/3 (2019): 885-907

Culler, Jonathan. Literary Theory: A very short introduction. Oxford University Press, 2011. https://doi.org/10.1093/actrade/9780199691340.001.0001.

Culler, Jonathan. "Why Lyric?," PMLA 123, no. 1 (2008):205. https://doi.org/10.1632/pmla.2008.123.1.201

Dobbs-Allsopp, F.W. "Psalms and Lyric Verse." N.p. Cited 22 October 2019. Online: https://www.academia.edu/3769980/Psalms_and_Lyric_Verse?email_work_car $\mathrm{d}=$ thumbnail.

Doidge, Norman. The brain that changes itself. Stories of personal triumph from the frontiers of brain science. New York: Penguin Books, 2007.

Dahood, Mitchell. Psalms I (1-50). Anchor Bible. New York: Doubleday, 1966.

Denis, Philippe. "Storytelling and Healing." Pages 5-17 in A Journey towards Healing: Stories of People with Multiple Woundedness in Kwazulu-Natal. Edited by Denis Philippe, Scott Houser, and Radikobo Ntsimane, Pietermaritzburg: Cluster, 2011.

Esterhuizen, Elizabeth. "A Study of the Tension between Despair and Hope in Isaiah 7 and 8 from a Perspective of Trauma and Posttraumatic Growth." D.Th thesis, UNISA, 2017.

Estes, Daniel J. "The Hermeneutics of Biblical Lyric Poetry." Bibliotheca Sacra 152, no. 608 (October 1995):413-430.

Eyerman, Ron. "Social Theory and Trauma," Acta Sociologica 56/1 (2013):41-53 https://doi.org/10.1177/0001699312461035.

Frechette, Christopher G. and Elizabeth Boase. "Defining 'Trauma' as a Useful Lens for Biblical Interpretation." Pages 1-23 in Bible through the lens of trauma. Edited by Elizabeth Boase and Christopher G. Frechette, Atlanta: SBL Press, 2016. https://doi.org/10.2307/j.ctt1h1htfd.4.

Garber, David G. Jr. "Trauma Theory and Biblical Studies", Currents in Biblical Research, (2015). N.p. Cited 22 October 2019. Online: https://doi.org/ $10.1177 / 1476993 X 14561176$.

Groenewald, Alphonso. "Micah 4:1-5 and a Judean experience of trauma", Scriptura, 116/2 (2017). N.p. Cited 22 October 2019. On-line: http://doi.org/10.7833/1162-1329.

Haney, Micah L. "Reading Joel as a Rhetorical-Therapeutic Response to Trauma." Ph.D thesis, Fuller Theological Seminary, 2019. Cited 22 October 2019. Online: https://search.proquest.com/openview/2b3fab1acb6ba492980707916d2f2830/1? pq-origsite $=$ gscholar \&cbl $=18750 \&$ diss $=y$.

Hawkes, Terence. Metaphor. London: Metheun, 1972.

Herman, Judith L. Trauma and Recovery. The Aftermath of Violence - From Domestic Abuse to Political Terror. New York: Basic Books, 1992.

Hug, Edward. "A Neuroscience perspective on psychodrama." Pages 227-238 in Psychodrama. Advances in Theory and Practice. Edited by Clark Baim, Jorge Burmeister and Manuela Maciel, London: Routledge, 2007.

Janet, Pierre. Les médications psychologiques. 3 vols. Paris: Société, 1919-1925, revised 1984.

Janzen, David. The Violent Gift. Trauma's Subversion of the Deuteronomistic History's Narrative. LHB/OTS 561. New York/London: Bloomsbury, 2012.

Johnson, David R. "Creative Therapies." Pages 112-144 in Effective Treatments for PTSD. Edited by E.B. Foa, New York: Guildford, 2000.

Johnson, Walter R. The Idea of Lyric: Lyric modes in ancient and modern poetry. Berkeley: Univ. of California, 1982. 
Jones, Serene. "Soul Anatomy: Calvin's Commentary on the Psalms.” Pages 265-284 in Psalms in Community. Jewish and Christian Textual, Liturgical, and Artistic Traditions. Edited by Harold W. Attridge and Margot E. Fassler, Atlanta: SBL, 2003.

LeDoux, Joseph. "Emotions: How I've looked for them in the brain." Pages 41-44 in Neuroscience and the person. Edited by Robert J. Russell, Nancey Murphy, Theo C. Meyering and Michael A. Arbib, Vatican City State: Vatican Observatory, 2002.

Linafelt, Tod. "Surviving Lamentations (one more time)." Pages 57-63 in Lamentations in Ancient and Contemporary Cultural Contexts. Edited by Nancy C. Lee and Carleen Mandolfo, Atlanta: SBL, 2008.

Lyon, Emily. "The Spiritual Implications of Interpersonal Abuse: Speaking of the Soul.” Pastoral Psychology, 59 (2010):233-247. https://doi.org/10.1007/s11089009-0238-2.

Mays, James L. Psalms. Interpretation commentaries. Louisville: John Knox Press, 1994.

McNally, Richard J. Remembering Trauma. Cambridge, MA: Harvard Univ. Press, 2003. https://doi.org/10.1038/nm1203-1448.

Medley, Michael. "A Role for English Language Teachers in Trauma Healing”, TESOL Journal, 3/1 (2012):110-125. https://doi.org/10.1002/tesj.6.

Miller, Patrick D. 1986. Interpreting the Psalms. Philadelphia: Fortress Press, 1986.

Newcomer, John W., Selke, Gregg, Melson, Angela K., Hershey, Tamara, Craft, Suzanne, Richards, Katherine, and Alderson, Arny L. "Decreased memory performance in healthy humans induced by stress level cortisol treatment." Archives of General Psychiatry, 56 (1999):527-533. https://doi.org/10.1 001/archpsyc.56.6.527.

Orr, Gregory. Poetry as Survival. Athens, GA: The University of Georgia Press, 2002. Poser, Ruth. "No Words: The Book of Ezekiel as Trauma Literature and a Response to Exile." Pages 27-48 in Bible through the lens of Trauma. Edited by Christopher Frechette and Elizabeth Boase, Atlanta: SBL, 2016.

Rahim, Jennifer A. "Reflections on Contemporary Christian Theologies of Suffering and the Value of Trauma Literature", MA thesis, Toronto School of Theology, 2016.

Rausch, Scott L., van der Kolk, Bessel A., Fisler, Rita E., Orr, Scott P., Alpert, Nathaniel M., Savage, Cary R., Fischman, Alan J., Jenike, Michael A., and Pitman, Roger K. "A symptom provocation study of posttraumatic stress disorder using positron emission tomography and script driven imagery", Archives of General Psychiatry, 53 (1996):380-387. https://doi.org/10.1001/archpsyc.1996. $\underline{01830050014003 .}$.

Ricoeur, Paul. The Rule of Metaphor. Toronto: University of Toronto Press, 1975-1979.

Rochester, Kathleen. "Reading the Exodus Story Alongside Case Studies of Abuse and Betrayal in Family Relationships", The Expository Times, 2018. N.p. Cited 22 October 2019. Online: https://journals.sagepub.com/doi/abs/10.1177/0014524 617731664.

Rollins, Wayne G. "The Bible and Psychology: New Directions in Biblical Scholarship," Pastoral Psychology, 45 (1997). N.p. Cited 22 October 2019. https://doi.org/10.1007/BF02251483.

Ross, Allen. A Commentary on the Psalms, 1:1-41. Grand Rapids: Kregel, 2011. 
Sacks, Sheldon. On Metaphor. Chicago: Univ. of Chicago, 1979.

Schacter, Daniel L. "Implicit Memory: History and Current Status." Journal of Experimental Psychology: Learning Memory, and Cognition, 13 (1987):501-518. https://doi.org/10.1037//0278-7393.13.3.501.

Schore, Allan N. "Right-Brain Affect Regulation." Pages 112-144 in The Healing Power of Emotion. Edited by Diana Fosha, Daniel J. Siegel, and Marion F. Solomon, New York: Norton, 2009.

Spronk, Klaas. 2018. "The avenging God of Nahum as comforter of the traumatized", Acta Theologica, 38, suppl. 26 (2018). N.p. Cited 22 October 2019. https://doi .org/10.18820/23099089/actat.Sup26.14.

Stone, Ken. "Safer texts: Reading Biblical laments in the age of AIDS," Theology and Sexuality, 10 (1999):16-27. https://doi.org/10.1177/135583589900501003.

Strawn, Brent A. "Trauma, Psalmic Disclosure, and Authentic Happiness." Pages 143160 in Bible through the lens of Trauma. Edited by Christopher Frechette and Elizabeth Boase, Atlanta: SBL, 2016. https://doi.org/10.2307/j.ctt1h1htfd.11.

Stulman, Louis. "Reading the Bible through the Lens of Trauma and Art." In Trauma and Traumatization in Individual and Collective Dimensions: Insights from Biblical Studies and Beyond. Edited by Eve-Marie Becker, Jan Dochhorn, and Else Holt, Göttingen: Vandenhoeck \& Ruprecht, 2014. https://doi.org/10.13 109/9783666536168.177.

Stulman, Louis. "Reflections on the Prose Sermons in the Book of Jeremiah: Duhm's and Mowinckel's Contributions to Contemporary Trauma Readings." Pages 125142 in Bible through the lens of Trauma. Edited by Christopher Frechette and Elizabeth Boase, Atlanta: SBL, 2016. https://doi.org/10.2307/j.ctt1h1htfd.10.

Symonds, Martin. "Victim Responses to Terror: Understanding and Treatment." Pages 95-103 in Victims of Terrorism. Edited by Frank M. Ochberg and D. Soskis, Boulder, CO: Westview, 1982.

Tsur, Reuben. Poetic Rhythm: Structure and Performance. Sussex: Academic Press, 2012.

Van der Kolk, Bessel A. and van der Hart, Onno. "The Intrusive Past: The Flexibility of Memory and the Engraving of Trauma." Pages 158-182 in Trauma. Explorations in Memory. Edited by Cathy Caruth; Baltimore: John Hopkins University Press, 1995.

Vaughan-Evans, Awel, Trefor, Robat, Jones, Llion, Lynch, Peredur, Jones, Manon W., and Thierry, Guillaume. "Implicit Detection of Poetic Harmony by the Naïve Brain”, Frontiers in Psychology (2016). N.p. Cited 22 October 2019. https://doi.org/10.3389/fpsyg.2016.01859.

Villanueva, Federico G. The Uncertainty of a Hearing. A study of the sudden change of mood in the psalms of lament. Leiden: Brill, 2008. https://doi.org/10.1163 lej.9789004168473.i-290.

West, Gerald O. "Between Text and Trauma: Reading Job with people living with HIV." Pages 209-230 in Bible through the lens of Trauma. Edited by Christopher Frechette and Elizabeth Boase, Atlanta: SBL, 2016. https://doi.org/10.2307/ j.ctt1h1htfd.15.

Westermann, Claus. The Living Psalms. Trans. J.R. Porter. Edinburgh: T\&T Clark, 1989.

. Praise and Lament in the Psalms. USA: John Knox Press, 1981. 
Dickie, "Healing of Trauma Memories," OTE 32/3 (2019): 885-907

Yates, Wilson. "Intersections of Art and Religion," Arts: The Arts in Religious and Theological Studies 10/1 (1998):17-24.

Zeman, Adam, Milton, Fraser, Smith, Alicia, and Rylance, Rick. 2013. "By Heart An fMRI Study of Brain Activation by Poetry and Prose", Journal of Consciousness Studies, 20/9-10:132-158.

June Frances Dickie, University of KwaZulu-Natal, South Africa. E-mail: junedickie@ @mail.com. ORCID: http://orcid.org/0000-0002-5226-5874. 